\title{
Equalizing the Use of Language: A View to Kosovo Law's Guarantees Upon Minority Languages
}

\author{
Dren Doli, Ketrina Cabiri* and Fisnik Korenica
}

Group for Legal and Political Studies, 'Gustav Majer' str. A1/5, Prishtina 10 000, Kosovo

\begin{abstract}
Kosovo through its Constitution proclaimed itself a multiethnic society, while attributing to its institutions the burden to preserve the ethnic minorities' identity, including their linguistic individuality. With a view to that, Kosovo authorities issued the necessary laws to make multiethnicity a 'living principle', thus establishing sufficient consociational elements in the Kosovo's legal system. With a view to that, this paper will make a review upon the Kosovo Law on the Use of Languages, and shall view the latter toward the principles set, by both, Ahtisaari Plan's provisions and Kosovo Constitution's provisions. Hence, apart from providing a critical evaluation, the paper is aimed at displaying the guaranteed mechanisms and principles employed by the law concerned for either upholding or assuring the use of language by ethnic minorities.
\end{abstract}

Keywords: Democracy - Conventions-Minorities rights- Ahtisaari Plan - Languages - Equality - Ethnic minorities- IdentityConsociational Democracy.

\section{INTRODUCTION}

Kosovo status settlement did invoke a number of internationally driven negotiations, which ended up with a plan designed by the UN special envoy Marti Ahtisaari. The latter did introduce the so-called Ahtisaari Plan, (Officially named as 'Comprehensive Proposal for the Kosovo Status Settlement, UN Doc. S/2007/168/Add. 1', hereinafter: CPKSS, 2007) which established the basic principles to be applied upon the Kosovo polity. Throughout the negotiation process a special consideration was given to the provisions establishing the ethnic minority rights and the standards to be respected, both through enabling the ethnic minorities a morethan-equal representation in the Kosovo institutions and through providing genuine guarantees for their cultural and linguistic identity. In this vein, Tansey (2009, p. 59) acknowledges that the Ahtisaari Plan provided an extensive protection for the Serb minorities and designed new decentralization framework, which 'meant to ensure that most Serbs would live in majority-Serb municipalities'.

Therefore, the plan concerned mostly relied upon the guarantees directed to enforce the position of the minorities within their municipal borders. However, as Kostovicova (2008, p. 636) asserts 'the plan relied on the weight of group rights and new municipal borders to address Serb insecurities and co-opt the Serbs into accepting an independent Kosovo.'

However, after the Kosovo people representatives declared the Kosovo independence, the Constitution had to, as a matter of the international political agreement, employ the

*Address correspondence to this author at the Group for Legal and Political Studies, 'Gustav Majer' str. A1/5, Prishtina 10 000, Kosovo;

Tel: +377 44188 838; Int: +44 7531591253 ;

E-mail: ketrina.cabiri@legalpoliticalstudies.org principles and guarantees defined by the Ahtisaari Plan. Moreover, all provisions related to the ethnic minority rights, had to, either through constitutional provisions or promulgation of laws, be ensured. Thus, later on, the Kosovo Constitution, as required by the Ahtisaari Plan, invoked the principles concerned and proclaimed Kosovo a multi-ethnic state, oriented to preserve the rights and ethnic identity of the minorities living within Kosovo. In term of numbers, it should be noted that as by the latest estimations Kosovo population is around 2.100 .000 and roughly $92 \%$ of the population is ethnic Albanian, 5.3\% ethnic Serbs, Turks comprising of $0.4 \%$ and Roma, Bosnians, and Gorani comprising of $2.3 \%$ of the population. [(According to the 2006 estimations of the Kosovan Statistical Institute (ESK, 2008) the Kosovo's population is composed of: Albanians - 92\% (1.932.000), Serbs- 5.3\% (111.300), Turkish - 0.4\% (8.400), Roma - 1.1 $\%$ (23.512), and others $-1.2 \%$ (24.788)].

Subsequently, Ahtisaari Plan provided for a new design in terms of new municipal borders' regulation, meaning that, it foresees a number of new Serb municipalities to be established [(For more on new municipalities see (CPKSS, 2007) and (AKM, 2008)] In this regard, the concerned municipal design offered some distinguishable features. First, it resolved Serbian fears of absorption and assimilation and provided for them a Serbian-led municipality, second, it provided the possibility to institutionally protect the rights of their communities, and third, opened the possibility to further develop their individual and cultural identity. As a matter of fact, Kosovo Constitution did expressly provide a provision which accepted the supremacy of the Ahtisaari Plan towards the constitutional provisions and other legal acts (Constitution of the Republic of Kosovo, article 143, paragraph 3, hereinafter: CRK, 2008) which was a step further to assure that any circumvention upon the guarantees for ethnic minorities might not take place. Moreover, Kosovo Constitution (2008, Chapter III, articles 57\&62), apart from offering 
a special chapter for the rights of minorities and their members, proclaimed a number of principles to be applied by its institutions, especially regarding the use of ethnic minorities' languages. Again, it should be noted that the contemporaneous debate upon the incentives to guarantee the ethnic minorities' rights and especially language rights as it is the case of Kosovo is explained 'in part by the general re-emergence of minority rights as a pressing issue in the wake of the fall of Communism in the former Eastern Bloc and the ensuing outbreak of ethnic tensions in central and eastern Europe, (Dunbar, 2001, p. 90).

Hence, it can be said that Kosovo has displayed a distinctive model of democracy, firstly, through employing a very broad cultural autonomy for ethnic minorities, secondly, through producing a proportional representation of the minorities, thirdly, through recognizing and setting a minority veto, and fourthly, through introducing a grand-coalition government, in terms of minorities' representation. All the latter characteristics fit within the Lijphart's (2008) concept of the so-called consociational democracy, thus vesting to Kosovo pretty unique democratic features. However, more particularly, the paper will make a review upon the guarantees stipulated by both the Ahtisaari Plan and the Kosovo Constitution, and consider the principles set by the latter. Of course, our main focus will be limited only to the guarantees on the use of languages for ethnic-minorities, however the response shall be delivered through observing the utilisation of the latter principles by the Kosovo Law on the Use of Languages. During the course of the paper, the discussion shall search whether the concerned guarantees present a sufficient basis for ethnic-minorities to preserve their ethnicidentity and as a result their linguistic identity. Furthermore, while making the legal review of the Law on the Use of Languages, the paper shall be offering a critical evaluation upon its provisions also. Thus, it is worth-noting that the Kosovo Law on the Use of Languages (No. 02/L-37, hereinafter: LUL, 2006) consists of 4 parts and 38 articles. Preliminarily, the concerned law provides the general object of itself and the purpose of its promulgation. The concerned law contains provisions which define the use of language by ethnic-minorities in central and municipal institutions, in public enterprises, in judicial proceedings, and the use of language while receiving education. Moreover, the law contains provisions regulating the use of language in media, the use of language in private sphere, and provisions defining the responsibility of the institutions to implement the law, administrative penalizations and sets-up the language commission. Prior to involve our self in the review of the provisions of the law, let's view the constitutional and Ahtisaarian guarantees upon the ethnic-minorities' right on language.

\section{EXPLAINING THE PRINCIPLES AND OBLIGA- TIONS IN THE LIGHT OF THE CONSTITUTION OF KOSOVO AND AHTISAARI PLAN}

As previously mentioned, Ahtisaari Plan establishes the main provisions as regards the ethnic minority rights to be later on sanctioned by the Kosovo Constitution, and in the light of that, vests the Kosovo institutions with the burden to implement them. Therefore, Kosovo Constitutional Commission built a Constitution [and consequently Kosovo Assembly adopted the Constitution in June 2008], which respects mainly all the requirements set-forth by the Ahtisaari Plan, while reinforcing the latter legal effect through preserving the primacy of it towards itself and other legal acts [(Constitutional Commission has been appointed to write and built the Kosovo Constitution in the light of Ahtisaari Plan requirements. For more see: Decree of the Kosovan President on the appointment of the Kosovan Constitutional Commission (2008), (CPKSS, 2007, article 10). Regarding the ethnic minorities' participation in the Constitution Commission see: (Tunheim, 2009)].

Ahtisaari Plan defined Kosovo a multi-ethnic society, a principle also established in the Kosovo Constitution (CPKSS, 2007 1(1) and CRK, 2008, 3(1)). The rationale standing behind it aims at, first, establishing an equal position for ethnic minorities in Kosovo, and second, expressing multi-ethnicity as a governing principle of the Kosovo polity. Furthermore, it can be said that the concerned principle provided a sufficient basis to build up a multi-ethnic governing rationale. Having said that, we argue that the preservation of ethnic minorities' cultural, linguistic and religious identity will only take place if such guarantees are to be applied. Admittedly, a recent report on the issue of use of language in the European Union asserts that '...most of the European nations have been built on the platform of their language of identity, the European Union can only build on a platform of linguistic diversity... A common sense of belonging based on linguistic and cultural diversity is a powerful antidote against the various types of fanaticism...' (EU Commission, 2008). In that vein, the Kosovar human rights' system aims at providing the connotations concerned to its system of protection of the linguistic identities.

Ahtisaari Plan, and in that stand, the Kosovo Constitution ascertains that the official languages of Kosovo shall be Albanian and Serbian. Other languages such as Turkish, Roma and Bosnian shall have the latter status on national and municipal level, as long as a law so determines (CPKSS, 2007 1(6), and CRK, 2008 5(1\&2)). Ahtisaari Plan and Kosovo Constitution are very careful to determine that any discrimination on the basis of language shall be prohibited, while proclaiming the equality before the law (CPKSS, 2007 2(2) and CRK, 2008 23(2)).

In the course of its determinations, Ahtisaari Plan provided that the law on use of languages shall be adopted by the Kosovo Assembly, while arguing that the adoption, amendment or repeal of the latter shall involve the principle of 'double- majority'. Explained in other words, the double majority principle means that the law shall be adopted, amended and/or repealed when at least both the majority of the Assembly members that are present and vote by representing the majority of population and the majority of Assembly members that are present and vote representing the ethnic-minorities [Serbian, Bosnian, Turkish, Roma, Egyptians] in the Assembly (CPKSS, 2007 1(3) and CRK, 2008 81(1)). This principle ensures that in any circumstance the Law concerning the use of languages [that is qualified as a law of vital interest], may not be repealed or amended by the political parties representing the majority of population in Kosovo [Albanians], unless a consensus with the representatives of ethnic minorities shall be reached. Moreover, no such law may be adopted, amended and/or repealed unless the Serbian ethnic-minority will vote for, due to the fact that Serbian representatives shall have 10 out of 20 reserved seats 
in the Assembly. In that regard Tansey $(2009$, p. 161) acknowledges that 'proposed laws affecting such "vital interests" as language, education, and communal symbols must win concurrent majorities in order to pass: Not only must a majority of the Assembly as a whole vote in favor, but so must a majority of those legislators who represent the minority communities. Repeal of any law in these areas likewise requires concurrent-majority consent'.

While prescribing the Kosovo's duty to promote the spirit of tolerance, Ahtisaari Plan requires from the Kosovo's authorities to incorporate within its legal system [as it is done through Kosovo Constitution] the standards set on European Charter for Regional or Minority Languages [hereinafter: ECRML] and the Council of Europe's Framework Convention for the Protection of National Minorities (CPKSS, 2007, annex II, 2(2) and CRK, 2008 58(2)). However, there are three main concerns regarding the application and the effect of the ECRML. First, even though the Kosovan legal system has recognized direct applicability to the ECRML, still individuals may not file a complaint in any supranational court [as it might be the case with ECtHR] to enforce their guaranteed right, mainly because of two issues. The first issue is related with the fact that Kosovo is not a signatory member of the ECRML, and second because the ECRML itself relies upon the national enforcement system and national reporting system (ECRML, 1992, articles 15, 16 and 17).

The second concern is related with the limitations that the ECRML provides, hence, as Schilling (2008, p. 1237) argues, the "'objectives and principles" of that charter apply "within the territories in which [regional or minority] languages are used'. Accordingly, McRae (in Paulston, 1997, p. 79) considers that ' $[t]$ he principle of territoriality means that the rules of language to be applied in a given situation will depend solely on the territory in question' (However, according to the same author, the application of the language provisions might rely upon the principle of personality, which 'means that the rules will depend on the linguistic status of the person or persons concerned' McRae in Paulston, 1997, p. 79). The latter, therefore, in other words, means that the application of the rights provided by the ECRML are applicable and will have effect only upon the territories in which the concerned community and/or individual is residing. Again, the application is restricted as far as the competencies of the regional or municipal institution are concerned. Thirdly, again referring to Schilling (2008, p. 1238), another important concern is related with the 'contexts in which minority language rights are protected'. Therefore, here again, the ECRML only refers to the areas 'being only covered insofar as, or to the extent that, the public authorities are competent', without any possibility to engage other central institutions in the protection of the rights (Schilling, 2008, p. 1238). Furthermore, Schilling (2008, p. 1238) acknowledges that 'this raises the question whether the judicial and administrative authorities meant by those provisions are only those specifically competent for the area in question, or also nationwide, or such authorities situated in that area only accidentally.' Nevertheless, it should be noted that the Advisory Office of Good Governance has so far developed a plan to follow the implementation of the ECRML, and in the same time the Kosovan Government has adopted the Human Rights Strategy (See: http://www.humanrights-ks.org/?cid=1,18), which has a special focus upon the Charter concerned. However, the International Civilian Office has expressed its concerned regarding the implementation and the proper functioning of the national mechanisms for compliance with the ECRML (MIP Matrix, 2009).

Through numbering the rights of communities and their members, Ahtisaari Plan as well as Kosovo Constitution, determined that the communities living within Kosovo shall be entitled to express, maintain and develop their culture and preserve the essential elements of their language (CPKSS, 2007 annex II, 3(1) and CRK, 2008 59(1)). Furthermore, the latter shall have the right to receive public education at all levels in their language, to establish and manage their private-run educational and training centers, to use the language and the alphabet thereto. Therefore, the minorities' right to freely use the language and the alphabet is extended in their relation with municipal and central authorities, and when required, the costs of an interpreter shall be acquired by the competent authorities (CPKSS, 2007 annex II, 3(1) and CRK, 2008 59(1)). It is worth noting that the European Commission, has, through the European Partnership instruments and other political accession requirements, developed a particular policy line, while requiring form candidate countries and potential-candidate countries to focus upon the issue of language rights and other cultural-related rights (Urrutia and Lasagabaster, 2007).

Additionally, the right to have their personal names registered in their language and to have local streets named in their language is guaranteed by the Constitution and Ahtisaari Plan (CPKSS, 2007 annex II, 3(1) and CRK, 2008 $59(1)$ ). In that vein, the right to have access and to have a special representation in public broadcasts, including the right to design the programmes in their language shall be preserved, without any limitation to establish media, provide information, either through daily newspapers or wire services and to secure a number of frequencies for electronic media, and finally the right to have a licensed independent Serbian language television channel (CPKSS, 2007 annex II, 3(3) and CRK, 2008 59(10\&11)). It should be noted that the Serbian communities in Kosovo are granted with a right to use the textbooks, curricula and other study programmes as prepared be the Ministry of Education of Serbia upon a prior notification of the Kosovo authorities and a right to set-up public universities in their language (CPKSS, 2007 annex III, article 7). Having considered the above, we might note that Ahtisaari Plan and Kosovo Constitution have followed a very moderate and liberal approach towards ethnic minorities, whereas have included a number of rights and international standards to be per se applied within Kosovo legal system.

Considering the use of language a fundamental principle of Kosovo polity, the Kosovo Constitution (2008, 29(2)) has not shown reluctance to guarantee that everyone who, for any reason, might be deprived of liberty, shall be informed upon the reasons of the deprivation in the language that he/she knows and proper understands. Moreover, the right to use the language is extended to the person accused or charged with a criminal offence, whereas the Constitution $(2008,30(1 \& 4))$ obliges the institutions concerned to inform a person in the language which the person understands, and 
where necessary, on the expenses of the concerned institution, to take assistance from an interpreter during the court proceedings.

Finally, Ahtisaari Plan required from the Kosovo Assembly to adopt [which it did] a law which implements the rights of communities and their members, (CPKSS, 2007 annex I, 7(7) $\mathrm{b}$ and annex XII, 2(1)) [following the procedure which respects the double-majority principle], which in our perspective, contains some other guarantees regarding the preservation of linguistic identity of all ethnic-minorities. Therefore, the concerned law materializes some of the above Constitutional and Ahtisaaarian guarantees, but also pays some attention to the right of freedom of expression, including the right to obtain and communicate information and ideas in the language one understands (Law No. 03/L-047 on the Protection and Promotion of the Rights of Communities and their Members, article 4, paragraph 3, hereinafter: LPPRC, 2008). In that line, the concerned law (LPPRC, 2008 4(9)), obliges Kosovo authorities to take affirmative measures in order to ensure that the languages other than official languages [Albanian and Serbian] shall be preserved, maintained and promoted, while, framing the Kosovo institution's actions in line with, and according to, the European Charter for Regional and Minority Languages.

As we might have perceived, central to Ahtisaari Plan and to the Kosovo Constitution is the 'living' of multiethnicity. Thus, as we viewed, the concern to build a polity which preserves the latter principle was of utmost intend. In addition, by reviewing the guarantees inquired to be implemented from both Ahtisaari Plan and Kosovo Constitution, we delivered a prism for better understanding the complexity of a living multi-ethnicity, being focused only upon the guarantees on the preservation and promotion of the use of languages.

As read between the lines, the purpose of the Ahtisaari Plan and subsequently of the Kosovo Constitution was to preserve the right on the use of language as a collective right and to guarantee the latter as an uncontested individual right.

In that line, Dunbar (2001, p. 90) acknowledges that the language rights of ethnic minorities are related to the consideration that the 'language is a fundamental constitutive element of personal identity' and the 'the existence of a secure and supportive cultural and linguistic environment is an important factor in an individual's personal development. Such an environment is, however, much more likely to exist for members of cultural and linguistic majorities than for members of minorities.' Therefore, the Ahtisaari Plan and the Kosovo Constitution have developed a system that embraces both elements, first, through guaranteeing the right on the use of language as an individual right, and second, through building new municipal borders and guarantees which would offer to the communities the required 'secured environment' necessary for the protection of their 'communitarian' values. Admittedly, there are still open questions whether the language rights fall within the categories of individual rights or group rights. If so, what then does an individual right in this case imply. Accordingly, some suggestions regard the right on the use of language as 'the most direct expression of culture; it is what makes us human and what gives each of us a sense of identity' (EU Commission, 2005). However, Schilling (2008) considers that the right to use the language is a personal right (which is part of the 'right on private life'), merely, a subjective right, and in the same time an essential part of the concept of human dignity. Further, there are some considerations that the right on the use of language is not only an individual right but it transcends the limits of the latter. As Langerpetz (1998, p. 184) acknowledges, there are certain distinguishable features for a collective right comparing to the individual right [('(1) The holder of a group right is a group. (2) A group right reserves the enjoyment of a good exclusively for the members of the group. (3) Group rights are granted because the existence of the group is intrinsically valuable.')]. However, Sniderman (et al., 1989, p. 260) considers that 'since language rights represent claims of entitlement, not only on behalf of individuals but also on behalf of communities, they raise deep questions of identity and affinity'. To that end, it should be noted that the language policy in Kosovo, notwithstanding the above debatable points, has referred to the right on language both as an individual and collective right.

It is still contestable whether the system of the language rights established by the Ahtisaari Plan and the Kosovo Constitution have intended the empowerment of the minorities [to make their own choices], without firstly being asked to set a balance 'between freedom to use one's language and freedom from being discriminated against for doing so' (Macias in Hornberger, 1998, p. 454-456). Nevertheless, whether the provisions of the Kosovo legal system regarding the use of languages and the protection of the language identities of the minorities [as a communitarian approach] should produce the expected effect in practice still stands as an opened question. However, the logic followed has a likeliness to have positive outcomes, since, as an OSCE report (1999, section III (d)) concludes that 'linguistic rights, and minority rights in general, help ensure that minorities are able to realize and enjoy rights that the majority might be able to enjoy on its own'.

After considering the above obligations vested upon Kosovo, let's now, on the coming part, embark on a detailed legal review of the Law on the Use of Languages.

\section{WHAT DOES THE LAW GUARANTEE? EXPLAIN- ING THE MATERIALIZATION OF MULTI- ETHNICITY BY THE CONCERNED LAW}

The following part of the paper is dedicated to the review of the Law on the Use of Languages [hereinafter the Law], commencing with the preamble and subsequently with other general and specific provisions part. The Law is divided in four parts: the first part delivers the general provisions [the principles proclaimed and guaranteed], whereas the other parts set-up the provisions regulating specific language guarantees. Nevertheless, there are certain objectives that a language policy in a given country has. According to Schilling (2008, p. 1220), the objective of the language policy is a three-fold one. First, it intends to provide the possibility that 'citizens may use [language] in their communications with public authorities and vice versa', second, the purpose is to define the 'languages accepted in parliamentary debates' and thirdly, to define the languages in which the legal acts are to be published and equally valid. According to the latter, the very object of the language policy is the "communication variable' state-citizen. Therefore, many other identity related 
objectives are not included. However, as regards the decision of a given state to introduce an official language or some official languages in inter 'state-citizen' communication, according to Langerspetz (1998), it 'unavoidably affects the distribution of burdens and benefits between citizens'.

Given the importance of the purpose of the language policy in a given country, the Kosovan law rather proclaims its intention to preserve and respect the linguistic identity of ethnic minorities. Considering the existence of a number of ethnic communities in Kosovo, the law oriented its focus upon the preservation of the linguistic identities, rather than orienting it toward state-citizen communication. In addition, it makes a direct reference to International Treaties whose aim is to set principles and standards for the protection of ethnic minorities' rights and identities. Therefore, we argue that, the latter reference upon the International Conventions will indirectly guide the future interpretations [by the Kosovo Authorities] of the provisions of the law, in line with, and according to the principles set by the concerned conventions. Moreover, the Law acknowledges that the use of language [ethnic minority languages] in the Kosovo institutions and organizations and enterprises functioning under the public law, the equal status of the Albanian and Serbian languages, and an equal use of the latter within Kosovo institutions shall be the purpose of itself [(Law No. 02/L-37 on the Use Languages (2006), article 1, paragraph 1, hereinafter: LUL, 2006)]. Considering the multilingual character of Kosovo society as a unique cultural feature, the concerned law has the intention to preserve, maintain and promote the linguistic identity. In addition, apart from Albanian and Serbian languages' status, the Law determines that Turkish, Bosnian and Roma shall have the official language status at the municipal level (LUL, 2006 1(1\&2).

\section{THE USE OF LANGUAGES IN KOSOVO INSTITU- TIONS}

Albanian and Serbian languages and their respective alphabets shall have an equal status as official languages of Kosovo, and all persons using them shall be treated equally (LUL, 2006 2(1\&2)). Any ethnic-minority language which constitutes at least 5 percent of the population of the concerned municipality shall have the status of the municipal official language, and shall be in equal use with other official languages (LUL, 20062 (3)). The law requires that the mother tongue of the ethnic minorities which represent above 3 percent of the population of the municipality, shall have a status of the language in official use (LUL, 2006 2(4)), which in other words, provides a right [for every members of ethnic minority], to present oral or written submission of documents and to receive a reply in the language they understand (LUL, 2006 8(1)). Thus, this right is extended to use the language in work and meetings of the municipal institutions and on the public hearings organized by the latter, providing where needed, interpretation and translation of any document presented thereof (LUL, 2006 8(4)). As a matter of fact, OSCE (2008) considers that with some exemptions, interpretation is provided in those municipalities, when such a request is submitted by any person.

The law $(20068(1,2,3))$ obliges the municipal institutions to ensure that any request directed to them [from any member of ethnic-minorities in their language], shall have a reply in that language, whereas the municipality shall publish the municipal regulations and subsidiary acts in the language of the concerned communities. It should be noted that, the law makes a distinction between the official language and languages in official use, providing that the official language shall have an extensive application in every public institution, and shall have an equal authoritative position upon its application, while the languages in official use will lack some of the particularities, given that the equal status language is not recognized to the latter cases.

Nevertheless, it should be pointed out that based on the ICO reports, Kosovo Government, so far, has ensured that no policies that have an aim to assimilate and to prevent the communities and/or individuals from using their languages are adopted (MIP Matrix 2009). However a report from OSCE (2008) concludes that the Kosovo Government has, so far, failed to implement the provisions of the law on use of languages as concerning the public awareness programme. In general, also as regards the installation of the bi-lingual traffic signs in national and regional roads, the concerned ministry has fulfilled its obligation (OSCE, 2008).

Moreover, the law reaffirms that every person shall have the freedom of expression, including the freedom to receive, seek and communicate information and disseminate information in the language he/she understands without intrusion. Suffice it to say for the moment, the law guarantees the right to receive cross-border broadcasting, which might be subject to the limitations compatible with international conventions, moreover, the Law confirms the prohibition of discrimination on the grounds of language (LUL, 2006 3(1\&2)). Consequently, the law guarantees that in the central institutions of Kosovo, the official languages [Albanian and Serbian] shall have an equal position, whereas the right of persons to communicate, and receive services and public documents in the official language shall be preserved (LUL, 2006 4(1\&2)). Hence, as regards official languages, the use in equal basis in the meetings [including public meetings] and work in the central institutions shall be guaranteed, therefore, in need basis, a proper interpretation and translation shall be made available. This right is granted to the individuals who on their individual choice decide to use the mother tongue in the meetings of the central institutions (LUL, 2006 4(4)). However, there is a clear inconsistent use of languages in the official documents issued by the Government, either in the form of adopted acts, or communications with the public (MIP Matrix, 2009). Therefore, all official records and official documents shall be issued in the official languages [Albanian and Serbian], including the displaying of the official names of the institutions (LUL, $20064(5 \& 6)$ ). It is worthnoting that all legal acts in the Official Gazette are published in Albanian, Serbian and English language (Humanitarian Law Centre, 2007).

The same rights are applied in the case of the Assembly of Kosovo proceedings and its committees and to the ethnic minorities' representatives [individually] deliberations, including the publication of all official documents (LUL, 2006 $5(1,2 \& 3))$. However as regards the implementation of the law on use of language by Kosovo Assembly a report of the Humanitarian Law Center (2007, p. 14) concludes that the concerned law has been 'fully implemented in the Assembly of Kosovo'. 
The Law (2006 5(4)) determines that Kosovo institutions' legal acts shall be adopted, issued and published in the official languages of Kosovo [Albanian and Serbian], provided that both versions shall be equally authoritative upon its application, furthermore the promulgated laws shall be published into the Bosnian and Turkish languages also. Subsequently, the law affirms the right of the ethnic minorities to make submission either oral or written to the Ombudsperson and consequently receive answers in the language that he/she understands (LUL, 2006, article 6).

It is worth-noting that the same rights granted [as mentioned above] either collectively or individually to the communities and their members, apply in the Municipal institutions also (LUL, 2006, article 7), adding that official names including the names of municipalities, villages, roads, streets and other public facilities shall be displayed in the official languages and languages having the official language status [of the concerned municipality] (LUL, 2006 9(2)). However, a survey conducted by the Humanitarian Law Center (2007, p. 1) concluded that 'concerning mono-national municipalities, the Law on the Use of Languages' provisions are respected more in areas with a predominantly Albanian population than in predominantly Serb areas.' But as regards the 'names of municipalities and municipal services, the names of employees in Albanian mono-national municipalities are mainly written in Albanian language, while in Serb municipalities they are exclusively written in Serbian' (Humanitarian Law Center, 2007, p. 3). However, 'Names of villages in multiethnic and mono-national Albanian municipalities are written in both Albanian and Serbian' (Humanitarian Law Center, 2007, p. 3). Nevertheless, the European Commission's (2009) latest report has reaffirmed that most of the municipalities have "not yet issued a regulation on the use of languages. Language courses among civil servants are not sufficient to enhance bi-lingualism within the administration.'

An important guarantee enshrined in the Law is the duty of the Publicly Owned Enterprises and Socially Owned Enterprises to apply the official languages while providing services and issuing documents, thus affirming the individual right of the ethnic minorities to communicate and receive documents from the latter in the language that he/she proper understands (LUL, 2006 11(1,2\&3)). Therefore, we argue that the latter obligation shall be extended to the cases when a private firm vested with public authority shall perform its public function, thus widening the scope of application of the concerned law.

\section{THE USE OF LANGUAGES IN JUDICIAL PROCEEDINGS}

The law stipulates that the official languages shall have an equal use during the judicial proceedings, and that it shall be in the duty of the Courts, Prosecution bodies, and other authorities involved in the criminal procedure to ensure the application [based on the choice of the parties involved] of one of the official languages (LUL, 2006 12(1\&2)). Furthermore, upon the request of the parties involved in the court proceedings, all documents presented or issued at or by the given court shall be in the official languages. The court shall make available for the parties simultaneous interpretation during the proceedings, if in the view of the court this shall serve to the public interest (LUL, 2006, articles $14 \& 15)$. Individuals arrested and/or charged for criminal offence are granted with the right to be informed in the language they understand [if that language is not an official language], moreover this right is applicable also during the court proceedings (LUL, 2006, articles 15\&16). The law preserves the right for the persons participating in criminal proceedings to make submissions, testify and be heard in the language that he/she understands. Thus, the law (LUL, 2006 $17(1 \& 2))$ makes a distinction between the right of the persons directly involved [either being accused or charged of an offence] and them participating for any reason at the proceedings, therefore guaranteeing the use of language they understand during the proceedings. With a view to the practical application, the Humanitarian Law Centre report (2007, p. 13) provides that 'simultaneous interpretation is provided in trials and all parties to the procedure follow the course of the hearing in their mother tongue... All judges receive necessary documents in their mother tongue.'

It is important to note that the Law (LUL, 2006, article 18) obliges the detention institutions to have their staff capable of communicating the language(s) of the majority of persons pursuing their prison term, and when needed interpretation should be provided. These guarantees have set a very important standard, firstly, by preserving the rights of communities as a whole, and secondly, by preserving the individual rights while expanding the rights of the detainees [as a special category of the society], and finally ensuring that the principle of fair and just trail shall take place.

\section{THE USE OF LANGUAGES IN EDUCATION}

The Constitution of Kosovo (2008, 47(1\&2)) guarantees the right to education to every person regardless of their race, gender, nationality or any other distinctiveness, and ensures that every citizen of the republic shall have equal opportunities to education. The question here is whether the right guaranteed by the Constitution might be utilized if there is no assurance that a person might pursue his/her education in the language he/she understands. Subsequently, the Law (LUL, 2006 19(2\&3)), by using the concerned logic, affirms that every person has a right to choose his /her preferred language of instruction and to enroll his/herself, or his /her child in a school where a language of instruction is understood by them. Furthermore, the Kosovo authorities shall ensure that the ethnic minorities, regardless of the status of their language, have the right to education in the language they understand, this is applicable in preliminary and secondary schools, and in their choice, they might set up private educational institutions in the language they consider appropriate (LUL, 2006, articles 19, 20, 21\&22). Nevertheless, as acknowledged by the European Commission's report (2009), Kosovo's education system provides curriculum taught in three languages (Albanian, Turkish, Bosnian). Also, in the primary schools, all textbooks are available in the languages concerned (EU Commission, 2009).

Official languages of Kosovo are the primary languages of instruction in public universities, and the use of any other language in specific study programs is to be determined by the universities themselves. The language used in university administration is left to be determined by the university regulations (LUL, 2006, article 23). Following that, an indi- 
vidual may request that their school record and reports be kept in the language he/she chooses, and it is in the duty of the Kosovo authorities to issue certificates and other documents in both official languages of Kosovo (LUL, 200624 $(1,2 \& 3))$.

Even though the Ministry for Education has established the Independent Commission for reviewing the Serbs' curricula, still there is a lack of confidence to attend the Kosovo public-run schools, rather in most of the cases the ethnic Serbs' pupils attend the so-called parallel-run institutions (financed illegally by the Serbian Government), and they follow the curriculums according to the Serbian Law (EU Commission, 2009). Nevertheless, the absence of curriculums in the Serbian language is preventing some other interested groups of children to get access to education (EU Commission, 2009).

Accordingly, as by the recent developments, both because of the non-implementation of the provisions of the law on the use of language in some parts of Kosovo (mainly north) and because of the impossibility of the publicly-run institutions (in terms of human resources) to provide education in different levels in Serbian language (primary, secondary and university studies), the education system is considered 'ethnically segregated' (Freedom House, 2009).

The latter provisions, apart from guaranteeing the right to education and to use the language while pursuing education, have followed an important logic that preserves the autonomy of the public and private educational institutions through guaranteeing the right to decide upon the language to be used during the instructions and while issuing and keeping their concerned documents.

\section{THE USE OF LANGUAGES IN MEDIA}

The law $(2006,26(1 \& 2))$ provides to every individual the right to establish media in the language(s) they consider appropriate. The public broadcaster is vested with the burden to promote cultural diversity and multilingual character of Kosovo, thus providing to the Communities a right to program-broadcast reserved-time in their languages (LUL, 2006 26(3)). Furthermore, taking into account the interest of the communities to have an equal opportunity and access to information, the public broadcaster shall ensure a reserved/special broadcasting time for the communities in the public broadcaster (LUL, 2006 26(3)). However, the requirement to broadcast $15 \%$ of its programs in the nonAlbanian languages is not met by the public broadcaster (EU Commission, 2009). Territorial coverage is lower that required (less than 90\%) in the minorities municipalities, due to the capacities of the public broadcaster (EU Commission, 2009). It should be noted that, the obligation of the Public Broadcaster to provide programmes in the minorities language is monitored thorough the Implementation Monitoring Council (IMC) (MIP Matrix 2009). In the same time, there is a permanent requirement of the ICO (International Civilian Office) directed to the Kosovan Government to adopt a plan allowing the Serbian language TV station to reach all Kosovo, however the latter is not possible because Kosovo is still not a member of the ITU (International Transmission Union) (MIP Matrix, 2009).

\section{THE PERSONAL NAMES AND LINGUISTIC FREEDOM}

Every person shall have a right [as determined by the Law] to write into the public register, personal identification and other official documents, his/her name and surname in the official language that he chooses. In cases where the person whose mother tongue is not one of the official languages of Kosovo, upon his/her request the name and surname shall be registered in the public document and other related registers in the language he/she understands and following the alphabet of the concerned language (LUL, 2006 27(1\&2)). However, there are unified civil registration forms that could be found in Albanian, Serbian and English, "while in Prizren/Prizren, Gjilan/Gnjilan, and South $\mathrm{Mi}$ trovicë/Mitrovica, they are also written in Turkish' (Humanitarian Law Centre, 2007, 2).

The law (LUL, 2006, article 28) guarantees the right of every citizen to establish and maintain legal persons such as associations of culture and business enterprises in their language, and also extending this to the right to display the names of the latter on the basis of alphabet of the languages concerned. The latter provisions also guarantee that ethnicminorities may have a right to establish and perform activities with non-governmental organizations and/or businesses without being constrained on the language basis.

\section{THE USE OF OFFICIAL LANGUAGES IN THE PRIVATE SPHERE}

The law (LUL, 2006 29(1\&2)) guarantees to every person the right to use the language he/she understands [or chooses] in the private enterprises, private institutions, associations, organizations or in self-employed activities, adding that Kosovo authorities may approve the application of other languages, when deemed that the use of other languages [not official languages] may induce the public legitimate interest such as public order, public safety, health or the protection of the rights of other persons and with the aim of supervising the public administration. The rationale of the latter provisions is to enable every individual pursuing his/her private activities to use the official languages, however Kosovo institutions may authorize the use of other languages [other than official languages] when reasoned under a legitimated public interest. Furthermore, the law (LUL, 2006 30(1\&2)) guarantees the right of every person to communicate and to receive services and documents from enterprises performing public services, and vests the concerned enterprises with the obligation to ensure the application of these individual rights. Additionally, in the municipalities where the status of official language is extended to other languages, the enterprises exercising public services have the obligation to offer the latter services in the official languages of the municipality (LUL, 2006 30(3)).

\section{THE LANGUAGE COMMISSION AND IMPLE- MENTATION MEASURES}

The Government of Kosovo is vested with the right to establish the Language Commission [hereinafter the Commission] whose burden is to supervise the implementation of the concerned law. Furthermore, the Commission has its utmost aim to preserve, promote and protect the official languages and their equal status, while guaranteeing the preservation of 
languages [whose mother tongue is not an official language] of other ethnic minorities (LUL, 2006 32(1)). The Commission has the right to take the appropriate measures and actions within its competences for ensuring that the principle of equality between official languages shall be preserved (LUL, 2006 32(2)). Therefore, the Commission shall commence the above mentioned actions in cases where: the equal status of the official languages was not or is not being recognized and in cases where any provision of any Law or sublaw act relating to the use of the official languages and/or languages of other ethnic minorities [whose mother tongue in not an official language], was not or is not in compliance with the law on the use of languages (LUL, 2006 32(3) i, ii).

The Law granted the right to the Commission to conduct ex-officio investigation and to mediate [when required], and upon the investigation carried out, to issue the recommendations on the required amendments or recommendations upon the improvements required in the concerned legal acts. In addition, in cases where such recommendations are not implemented within a reasonable time-limit, the Commission may issue a written warning, and the latter shall be included in the Commission's annual report [directed to the Assembly and Government] (LUL, 2006, 32(4, 5, 6, 7\&8)). The Commission may review [the sub-law act] and issue the concerned recommendations in cases where the sub-law act may affect or affects the status of the use of official languages and/or of the regulations issued to implement the law (LUL, 2006 32(9)). The establishment of a special body [Language Commission] to supervise the implementation of the law therefore is in itself a further guarantee for the right to use the language and preserve the linguistic identity of ethnic minorities. However, it should be noted that, as reported by the ICO, the Language Commission is not properly functioning due to the lack of human and financial resources (MIP Martix, 2009). In addition, if the Commission has been established as a monitoring body for the implementation of the law on the use of languages, and the latter financial resources and human capabilities are not sufficient, the proclaimed guarantees resulting from competencies of the Commission are very much endangered.

Finally, the law (2006, articles 31\&33) determined the obligation of the Kosovo authorities to adopt measures [sublaw acts] that ensure the respect for the language rights guaranteed and the administrative penalizations to be applied upon the violations of the law.

\section{CONCLUSION}

Based in the multiethnic proclamations of the Kosovo Constitution and the Ahtisaari Plan, the paper developed a logic of argumentation by, firstly, explaining the fundamental rights [regarding the use of language] guaranteed by the Constitution and the Ahtisaari Plan, and secondly, offering a legal review of the Law on the Use of Languages. The paper argued that Kosovo Constitution and Ahtisaari Plan established a very distinctive model of democracy, firstly, by preserving the cultural autonomy, secondly, by producing a proportional representation of the minorities, and thirdly, by granting a minority veto, which in our argument provides a consociational democracy model. Therefore, the right to use the language guaranteed by the latter acts followed the con- sociational democracy's logic, while, in the same time aimed to preserve the linguistic identity of the ethnic communities.

The paper, in its second part, provided a detailed legal review of the Law on the Use of Languages, while viewing the latter's provisions in the light of the consociational logic [established by the Constitution and Ahtisaari Plan] and questioning whether the guarantees on the use of language are well preserved by the law itself. Moreover, the paper distinguished the rights guaranteed by the law, firstly, by making a distinction of the right on the use of languages as a collective right [right pertaining to the ethnic community as a whole] and secondly, the right on the use of languages as an individual right [right related to a person - ethnic minority member]. In that vein, it can be concluded that the language policy in Kosovo has adopted the Sniderman's (et al., 1989, p. 260) approach, which argues that 'what is distinctive about language rights, though, is that a claim is made not simply on behalf of an individual but more fundamentally on behalf of a linguistic community.'

Finally, the paper displayed the guarantees enshrined in the law, starting from the right to use the language in the central and municipal institutions, in the public enterprises and while receiving services from the latter, subsequently, continuing with the right to use the language in judicial proceedings, media, education [primary, secondary and university level], and in the private sphere. In the end, the paper reviewed the law's provision concerning the Language Commission as a specialized body to supervise the implementation of the law and to further guarantee the preservation of the ethnic minority languages, and ended with the review of the administrative sanctions implied.

Hence, ultimately, one can conclude that Kosovo, through the Law on the Use of Languages, has made a big step forward in terms of the deep respect for human rights of ethnic minorities.

\section{ABOUT AUTHORS}

Dren Doli is a Senior Researcher at the Group for Legal and Political Studies and a Senior Lecturer of Law Principles at the Universum Institute for Economic and Social Studies, having served earlier as a Senior Legal Executive for Integration at the Kosovo Prime Minister.

Ketrina Cabiri is an expert of post-communist democratization, and a Research Fellow at the Group for Legal and Political Studies.

Fisnik Korenica is a Lecturer of the Theory of State and Law at the University of Prishtina. Korenica is also a Senior Researcher at the Group for Legal and Political Studies.

\section{REFERENCES:}

Dunbar, R. (2001). Minority language rights in International law. International and Comparative Law Quarterly 50, 90-120.

Hornberger, H. N. (1998). Language policy, language education, language rights: indigenous, immigrant, and International perspectives. Language in Society 27(4), 439-458.

Kostovicova, D. (2008). Legitimacy and International administration: The ahtisaari Settlement for Kosovo from a Human Security Perspective. International Peacekeeping 15(5), 631-647.

Lagerspetz, E. (1998). On Language Rights. Ethical Theory and Moral Practice, Multiculturalism, Nationalism and Liberal Democracy. Vol. 1, Issue 2, pp. 181-199. 
Lijphart, A. (2008). Thinking about Democracy. Power-Sharing and Majority Rule in Theory and Practice. New York: Routledge.

Paulston, B. C. (1997). Language policies and language rights. Annual Review of Anthropology 26, 73-85.

Schilling, T. (2008). Language rights in The European Union. German Law Journal 09(10), 1219-1242.

Sniderman, M. P., Fletcher, F. J., Russell, H. P., \& Tetlock E. P. (1989). Political culture and the problem of double standards: Mass and elite attitudes toward language rights in the canadian charter of rights and freedoms. Canadian Journal of Political Science / Revue Canadienne de Science Politique 22(2), 259-284.

Tansey, O. (2009). Kosovo: Independence and tutelage. Journal of Democracy 20(2), 153-166.

Tunheim, J. (2009). Rule of law and the Kosovo constitution. 18 Min. J. Int'1 L. 371.

Urrutia, I., \& Lasagabaster, I. (2007). Language rights as a general principle of community law. German Law Journal 08(05), 479-500, available at: http://www.germanlawjournal.com/pdfs/Vol08No05/PDF_Vol_08_No_05_479-500_Articles_Urruitia.pdf

Association of Kosovo Municipalities. (2008). Kosovo Municipalities: A Short Profile. Prishtina, available at: http://www.komunatks.net/dokumentat/20090416_144523_2.pdf

Comprehensive Proposal for the Kosovo Status Settlement, UN Doc. S/2007/168/Add. 1.

Constitution of the Republic of Kosovo. (2008). Available at: http://www.kuvendikosoves.org/?cid=2,100,48

Decree of the Kosovan President on the appointment of the Kosovan Constitutional Commission, 19 February 2008. Accessed at (30 March 2010):

http://www.kosovoconstitution.info/repository/docs/VENDIMI\%20 I\%20PRESIDENTIT\%20per\%20KKK.pdf

European Charter for Regional or Minority Languages. (1992). European Treaty Series no. 148. Council of Europe.

Freedom House. (2009). Freedom in the World, Country Report 2009, Available at: http://www.freedomhouse.org/template.cfm?page=$22 \&$ country $=7757 \&$ year $=2009$

Humanitarian Law Centre. (2007). Kosovo Institutions Applying the Law on the Use of Languages. Kosovo Report, October 2007, Available at:
http://www.hlcrdc.org/uploads/editor/Kosovo\%20Institutions\%20A pplying $\% 20$ the $\% 20$

aw\%20on\%20the \%20Use\%20of\%20Languages-

October\%202007\% $281 \% 29$.pdf

Law on the Protection and Promotion of the Rights of Communities and their Members, No. 03/L-047, Available at: http://www.gazetazyrtare.com/

Law on the Use Languages, No. 02/L-37, Available at: http://www.gazetazyrtare.com/

MIP Matrix: Implementation of the Comprehensive Settlement Proposal State of Implementation. ICO Document (2009), Available at: http://www.ico-kos.org/?id=6

Organization for Security and Co-operation in Europe. (1999). Report on the Linguistic Rights of Persons Belonging to National Minorities in the OSCE Area. OSCE: The Hague.

Organization for Security and Co-operation in Europe. (2008). Implementation of the Law on the Use of Languages by Kosovo Municipalities. OSCE (Mission in Kosovo) Monitoring Department, Available at: http://www.osce.org/documents/mik/2008/07/32145_en.pdf

Proposals from the Group of Intellectuals for Intercultural Dialogue set up at the initiative of the European Commission. (2008). A Rewarding Challenge: How the Multiplicity of Languages Could Strengthen Europe. Brussels, Available at: http://ec.europa.eu/education/policies/lang/doc/maalouf/report_en.pdf

Statistical Office of Kosovo (ESK). (2008). Report on: Ndryshimet demografike të popullsisë së Kosovës në periudhën 1948-2006, Seria 4: Statistikat e Popullsisë, Available at: http://www.ksgov.net/ESK/index.php?option=com_docman\&task=cat_view\&gid=8\&Ite $\operatorname{mid}=8$

The Commission of the European Union. (2005). Communication from the Commission to the Council, the European Parliament, the European Economic and Social Committee and the Committee of the Regions: A New Framework Strategy for Multilingualism. Brussels: COM (2005) 596 final.

The Commission of the European Union. (2009). Commission Staff Working Document: Kosovo under UNSCR 1244/99 2009 Progress Report accompanying the Communication from the Commission to the European Parliament and the Council. Brussels: SEC (2009) 1340.

(C) Doli et al.; Licensee Bentham Open.

This is an open access article licensed under the terms of the Creative Commons Attribution Non-Commercial License (http://creativecommons.org/licenses/by-nc/3.0/) which permits unrestricted, non-commercial use, distribution and reproduction in any medium, provided the work is properly cited. 